\title{
Pemberdayaan ibu PKK dalam pembuatan biopori berbasis limbah rumah tangga
}

\author{
Isna Rahma Dini ${ }^{* 1}$, Fauza Azmimelwa ${ }^{2}$, Joko Setiawan ${ }^{3}, \&$ Rachmad Saputra1 \\ ${ }^{1}$ Jurusan Agroteknologi, Fakultas Pertanian Universitas Riau \\ ${ }^{2}$ Manajemen, Fakultas Ekonomi dan Bisnis, Universitas Riau \\ ${ }^{3}$ Ilmu Ekonomi, Fakultas Ekonomi dan Bisnis, Universitas Riau \\ *isnarahmadini19@gmail.com
}

\begin{abstract}
Abstrak. Berbagai macam kegiatan yang dilakukan oleh ibu PKK dalam mengisi waktu bekerja di rumah saat pandemi covid-19 salah satunya adalah bercocok tanam di sekitar pekarangan rumah. Aktivitas bercocok tanam ini pastinya memerlukan pupuk berguna untuk meningkatkan kesuburan tanaman. Biopori merupakan salah satu upaya yang dapat dilakukan untuk meningkatkan kesehatan tanah dan memicu terjadinya proses dekomposisi bahan organik secara alami. Bahan organik yang digunakan dapat berasal dari sampah dapur. Selama ini biopori dikenal sebagai upaya untuk mengatasi genangan air dan masih belum banyak dimanfaatkan untuk peningkatan kesuburan tanah. Pengabdian ini bertujuan untuk memberikan informasi pembuatan dan aplikasi biopori pada tanaman sehingga dapat meningkatkan kesuburan tanah pada tanaman yang dibudidayakan. Metode yang dilakukan terdiri atas metode ceramah, praktek langsung, serta melakukan evaluasi capaian kegiatan dengan menggunakan alat ukur ketercapaian. Berdasarkan hasil evaluasi posttest yang dilakukan terjadi peningkatan pengetahuan ibu PKK tentang biopori di mana awalnya hanya 40\% meningkat menjadi $100 \%$. Selain itu, praktek langsung pembuatan dan aplikasi biopori dilakukan pada salah satu ibu PKK menjadi salah satu indikator tingginya minat ibu PKK dalam mengaplikasikan biopori. Hal ini dapat disimpulkan bahwa kegiatan pengabdian cukup efektif meningkatkan kemampuan dan minat ibu PKK dalam menerapkan biopori pada tanaman di sekitar pekarangan rumahnya.
\end{abstract}

Kata kunci: biopori, kesuburan tanah, limbah rumah tangga

\begin{abstract}
Various kinds of activities carried out by PKK mothers in filling their time working at home during the Covid-19 pandemic, one of which is farming around the yard. This farming activity certainly requires useful fertilizers to increase plant fertility. Biopores is an effort that can be made to improve soil health and trigger the natural decomposition of organic matter. The organic material used can come from kitchen waste. So far, biopores are known as an effort to overcome standing water and are still not widely used to increase soil fertility. This service aims to provide information on the manufacture and application of biopores in plants so that they can increase soil fertility in cultivated plants. The method used consists of lecturing methods, hands-on practice, and evaluating the achievement of activities using achievement measures. Based on the results of the posttest evaluation, there was an increase in the knowledge of PKK mothers about biopores, where initially only $40 \%$ increased to $100 \%$. In addition, the direct practice of making and applying biopores carried out on one of the PKK mothers is an indicator of the high interest of PKK mothers in applying biopores. It can be concluded that community service activities are quite effective in increasing the ability and interest of PKK mothers in applying biopores to plants around their house yards.
\end{abstract}

Keywords: biopores, soil fertility, household waste

To cite this article: Dini, I. R., F. Azmimelwa., J. Setiawan., \& R. Saputra. 2020. Pemberdayaan ibu PKK dalam pembuatan biopori berbasis limbah rumah tangga. Unri Conference Series: Community Engagement 2: 24-30. https://doi.org/10.31258/unricsce.2.24-30

(C) 2020 Authors

Peer-review under responsibility of the organizing committee of Seminar Nasional Pemberdayaan Masyarakat 2020 


\section{PENDAHULUAN}

Pandemi Covid-19 yang melanda di Indonesia sejak bulan maret 2020 hingga saat ini sangat banyak merubah kegiatan masyarakat terutama meningkatkan kegemaran masyarakat. Beberapa kegemaran masyarakat di antaranya yaitu bersepeda dan bercocok tanaman baik tanaman hortikultura maupun tanaman hias. Hal ini dilakukan untuk mengisi luang waktu selama melakukan kerja di dalam rumah. Hampir semua ibu-ibu melakukan budidaya tanaman di sekitar rumahnya seperti halnya yang terjadi pada kelompok ibu PKK (Pemberdayaan Kesejahteraan Keluarga) di Kelurahan Lembah Sari Kecamatan Rumbai Pesisir Kota Pekanbaru.

Upaya peningkatan kesuburan tanaman yang dilakukan oleh ibu-ibu PKK tersebut dilakukan dengan memberikan pupuk anorganik maupun pupuk organik seperti air cucian beras yang dihasilkan setiap hari oleh ibu-ibu PKK tersebut. Selain itu, sebagian ibu-ibu PKK juga telah memanfaatkan sayur-sayuran yang telah membusuk untuk dikomposkan maupun diletakkan di atas permukaan tanah dekat tanaman yang dibudidayakan. Akan tetapi, kegiatan tersebut tentunya membutuhkan waktu yang lama dan kurang efektif karena sayuran yang membusuk di atas permukaan tanah akan menimbulkan datangnya lalat dan menghasilkan bau busuk. Salah satu upaya yang dapat dilakukan untuk menanggulangi permasalahan tersebut yaitu dengan membuat biopori yang diletakkan berdekatan dengan tanaman yang dibudidayakan.

Menurut Zulaihah et al. (2018), lubang resapan biopori adalah teknologi tepat guna dan ramah lingkungan untuk meningkatkan daya resapan air, memanfaatkan peran aktivitas fauna tanah dan akar tanaman. Biopori dikenal sebagai suatu cara yang digunakan untuk mengatasi genangan air dengan cara membuat tabung silindris menggunakan pipa paralon yang dilubangi secara vertikal dan ditanam di dalam tanah. Itulah sebabnya biopori dikatakan sebagai lubang resapan atau sumur resapan karena dapat mengurangi kelebihan air pada permukaan tanah sehingga menghindari banjir. Upaya untuk meningkatkan resapan air pada biopori biasanya ditambahkan dengan sampah organik berupa serasah daun dan selanjutnya akan mengalami pembusukan secara alami oleh mikroorganisme yang tumbuh pada biopori tersebut. Hal ini berdasarkan pernyataan dari Santoso et al. (2018) yang menyatakan bahwa sampah organik yang berada di dalam lubang resapan biopori dapat memicu kehadiran organisme tanah seperti cacing, semut dan rayap. Kehadiran organisme tersebut dapat membantu dalam proses penguraian bahan organik tersebut dan selanjutnya menghasilkan unsur hara yang dibutuhkan oleh tanaman.

Berbagai macam sampah organik dapat diletakkan di dalam lubang biopori di antaranya yaitu serasah daun maupun sampah dapur. Menurut Permanasari et al. (2018), sampah dapur lebih cepat terurai dibandingkan dengan sampah serasah daun kering. Pemanfaatan limbah rumah tangga untuk pupuk organik juga dilaporkan oleh Abidin dan Rohman (2020), dimana sampah rumah tangga dapat menjadi pupuk organik cair maupun pestisida nabati. Hasil penguraian sampah ini dapat dimanfaatkan oleh tanaman dalam rangka meningkatkan kesuburan tanah. Hasil penelitian Mansur dan Wijaya (2019) terlihat bahwa pemanfaatan biopori pada tanaman dengan memanfaatkan berbagai macam limbah organik seperti daun LCC (Legum Cover Crop) dan sampah dapur dapat menigkatkan pertumbuhan tanaman jabon.

Aplikasi biopori skala kecil pada tanaman dengan menggunakan toples plastik bekas dan sampah dapur diharapkan dapat meningkatkan pertumbuhan tanaman di sekitar pekarangan rumah. Melalui biopori ini juga dapat menanggulangi permasalahan terhadap pemanfaatan sampah dapur yang diaplikasikan langsung pada permukaan tanah di sekitar tanaman, di mana kegiatan ini akan menghasikan bau dan menimbulkan datangnya lalat. Hal ini disebabkan karena toples yang digunakan untuk biopori tersebut ditutup dan hanya diberi lubang sedikit sebagai jalan masuknya oksigen. Selain itu, dengan adanya biopori maka ibu-ibu tidak perlu melakukan pembuatan kompos dari sampah dapur yang biasanya akan memakan waktu yang cukup lama.

Pemanfaatan biopori untuk meningkatkan kesuburan tanah belum pernah dilakukan oleh ibu-ibu khususnya kelompok ibu PKK di Kelurahan Lembah Sari. Oleh karena itu dilakukan pelatihan pembuatan biopori dalam rangka menjelaskan manfaat, cara pembuatan biopori dan aplikasi biopori pada tanaman sehingga nantinya dapat diterapkan oleh kelompok ibu PKK dalam meningkatkan kesuburan tanaman yang dibudidayakan.

\section{METODE PENERAPAN}

Kegiatan pengabdian ini dilaksanakan di aula pertemuan Kelurahan Lembah Sari Kecamatan Rumbai Pesisir Kota Pekanbaru dan dihadiri oleh anggota ibu-ibu PKK Lembah Sari. Metode yang digunakan pada kegiatan pengabdian ini terdiri atas metode ceramah, praktek langsung, dan melakukan evaluasi capaian kegiatan dengan menggunakan alat ukur ketercapaian. 


\section{Langkah-langkah kegiatan}

Kegiatan yang pertama kali dilakukan yaitu memberikan kuisioner (pretest) untuk mengukur sampai sejauh mana pemahaman peserta pada tema kegiatan pengabdian yang akan dilaksanakan. Selanjutnya tim pengabdian memaparkan materi tentang biopori, manfaat, cara pembuatan biopori dan aplikasi biopori pada tanaman. Penyampaian materi ini menggunakan powerpoint dan video dengan memanfaatkan laptop dan LCD. Selain itu, tim pengabdian juga membagikan leaflet tentang biopori sehingga nantinya peserta mudah melakukan pembuatan biopori secara mandiri setelah kegiatan pengabdian dilaksanakan. Praktek pembuatan biopori melibatkan sepuluh orang mahasiswa Kuliah Kerja Nyata (Kukerta) di Kelurahan Lembah Sari. Selain itu, mahasiswa tersebut juga mendampingi secara langsung dalam penerapan biopori di tanaman sekitar pekarangan rumah kelompok ibu PKK.

\section{Proses Pembuatan Biopori}

\section{Alat dan bahan dalam pembuatan biopori}

Alat yang digunakan dalam pembuatan biopori terdiri atas toples/botol plastik bekas dan solder. Botol plastik yang digunakan harus memiliki penutup sehingga mengindari air masuk ke dalam biopori. Solder digunakan untuk melubangi botol plastik yang akan digunakan untuk biopori. Bahan pembuatan biopori merupakan sampah rumah tangga yang tidak termanfaatkan lagi baik yang telah membusuk akibat penympanan terlalu lama maupun yang belum membusuk. Akan tetapi, sampah rumah tangga yang digunakan sebaiknya dihindari adanya kandungan minyak sehingga nantinya memperlambat proses dekomposisi pada biopori. Alat dan bahan dalam pembuatan biopori dapat dilihat pada Gambar 1.
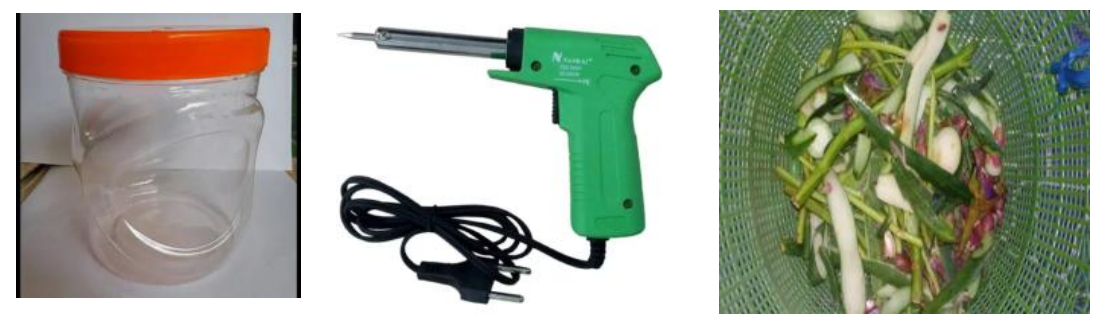

Gambar 1. Limbah organik

\section{Tahapan Pembuatan Biopori}

Beberapa tahapan pembuatan biopori di antaranya yaitu

1. Toples/botol yang akan digunakan dalam pembuatan biopori dibersihkan terlebih dahulu. Ukuran toples yang digunakan disesuaikan dengan jenis tanaman yang ditanam dan luasnya pot atau polibeg yang digunakan. Botol/toples tersebut selanjutnya dilubangi dengan menggunakan alat pelubang (solder atau paku) disekeliling botol setinggi 5-7 $\mathrm{cm}$ dari permukaan bawah botol.

2. Bagian tengah tutup botol/toples juga dilubangi sehingga udara dapat masuk melalui lubang tersebut.

3. Lubang yang di buat sebaiknya sejajar atau sama rata.

4. Jumlah lubang yang dibuat disesuaikan dengan diameter botol.

5. Botol yang di lubangi diisi dengan sampah dapur yang telah dicincang sehinggi dapat diharapkan limbah tersebut dapat terurai dengan cepat.

6. Botol yang telah berisi limbah tadi diletakan di dalam tanah berdekatan dengan tanaman yang dibudidayakan (sekitar 10-20 cm dari tanaman) dengan cara melubangi tanah. Sekitar 2/3 bagian botol disisakan sehingga bagian botol tetap dapat terlihat dari permukaan tanah (Gambar 2)

7. Jika isi botol telah mengalami penyusutan maka dilakukan penambahan limbah organik yang baru.

8. Diusahakan agar air tidak masuk ke dalam botol sehingga tutup botol harus selalu di tutup.

9. Jangan dibiarkan isi botol mongering yang akan mengakibatkan proses dekomposisi berhenti. 

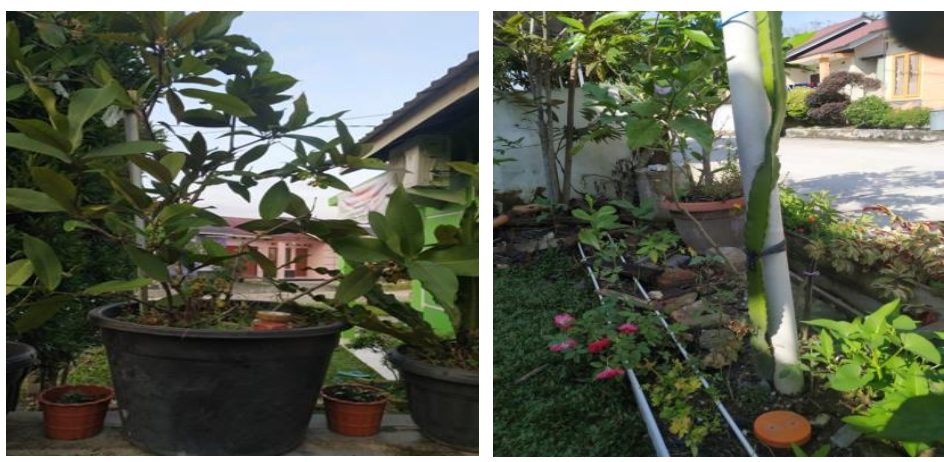

Gambar 2. Aplikasi biopori pada tanaman di sekitar tanaman yang ditanam di pekarangan rumah

\section{Alat Ukur Ketercapaian}

Evaluasi kegiatan sangat diperlukan untuk menentukan keberhasilan dalam pencapaian tujuan kegiatan pengabdian. Evaluasi dilakukan dalam dua pola yaitu evaluasi sebelum pelaksanaan pengabdian (pre-test) untuk menentukan skor dasar (base score). Kedua, evaluasi sesudah pelaksanaan pengabdian (post-test) untuk menentukan peningkatan pengetahuan masyarakat. Pre-test dan post-test yang akan diadakan dalam bentuk kuisioner. Hasil selisih antara pre-test dengan post-test diketahui sebagai parameter akhir keberhasilan pelaksanaan pengabdian.

\section{HASIL DAN PEMBAHASAN}

Kegiatan ini dilaksanakan berdasarkan meningkatnya kegemaran ibu-ibu PKK terhadap kegiatan bercocok tanam di sekitar pekarangan rumahnya. Selain itu, kegiatan ini juga dapat memanfaatkan sampah rumah tangga yang biasanya jarang dimanfaatkan oleh ibu-ibu pada tanaman yang mereka budidayakan. Kegiatan pengabdian ini dihadiri oleh ibu-ibu yang tergabung dalam kelompok ibu PKK sebanyak 30 orang. Jumlah peserta yang tidak begitu banyak ini disebabkan karena pelaksanaan kegiatan dilakukan pada masa pandemi covid-19 yang belum berakhir sehingga masih banyak ibu-ibu yang tidak turut serta dalam mengikuti kegiatan ini. Kegiatan ini dibuka oleh ketua tim pengabdian dan dilanjutkan dengan pemberian kata sambutan oleh Kepala Lurah Lembah Sari dan Ketua Kelompok PKK Lembah Sari. Kegiatan ini mendapat perhatian dan harapan besar mengingat bahwa selain pemanfaatan biopori untuk peningkatan kesuburan tanah, biopori ini juga sangat cocok jika diterapkan di Kota Pekanbaru yang sering menghadapi permasalahan genangan air.

Kegiatan ini dibagi menjadi dua sesi yaitu penjelasan tentang biopori dan demo pembuatan biopori dengan menggunakan botol plastik yang telah disiapkan oleh tim pengabdian. Sebelum diberikan penjelasan tentang biopori, dilakukan survey awal dengan pretest yang dapat menggambarkan tentang apakah ibu PKK telah mengetahui tentang biopori untuk meningkatkan kesuburan tanah. Berdasarkan hasil kuisioner yang telah diberikan terlihat bahwa hanya $40 \%$ peserta yang mengetahui biopori. Akan tetapi, pemahaman biopori yang diketahui hanya sebatas sebagai sumur resapan dalam menanggulangi genangan air. Semua peserta belum pernah mengaplikasikan biopori untuk meningkatkan kesuburan tanah pada tanaman yang mereka tanam di sekitar pekarangan rumahnya. Kegiatan survey awal (pengisian kuisioner pretest) dapat dilihat pada Gambar 3.

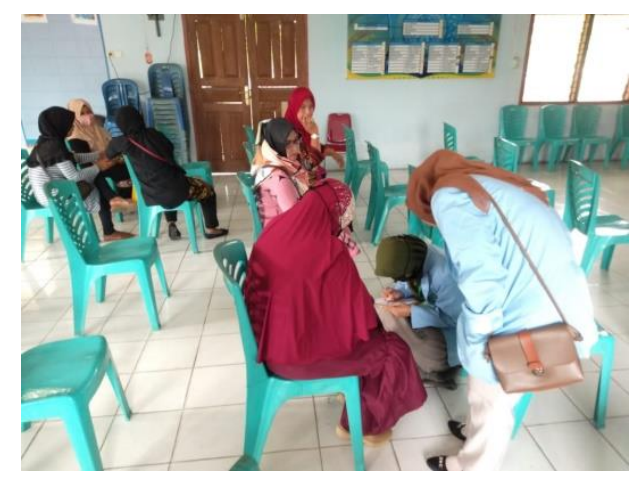

Gambar 3. Pelaksanaan pretest peserta sebelum kegiatan pengabdian dilaksanakan 
Kegiatan selanjutnya yaitu pemaparan oleh ketua tim pengabdian kepada peserta. Pemaparan dilakukan dengan menerangkan materi dalam bentuk slide persentasi dan video sehingga diharapkan akan lebih memudahkan ibu-ibu dalam memahami cara dan aplikasi biopori pada tanaman. Tim pengabdian juga memberikan leaflet yang berisi tentang materi biopori sehingga diharapkan dapat menjadi panduan untuk membuat biopori secara mandiri di rumah masing-masing. Setelah pemaparan, dilanjutkan dengan diskusi di mana peserta cukup interaktif dalam memberikan pertanyaan seputar biopori. Hal ini disebabkan karena biopori yang dijelaskan sangat sederhana untuk mudah diterapkan oleh ibu-ibu. Kegiatan pemaparan oleh tim pengabdian dapat dilihat pada Gambar 4.
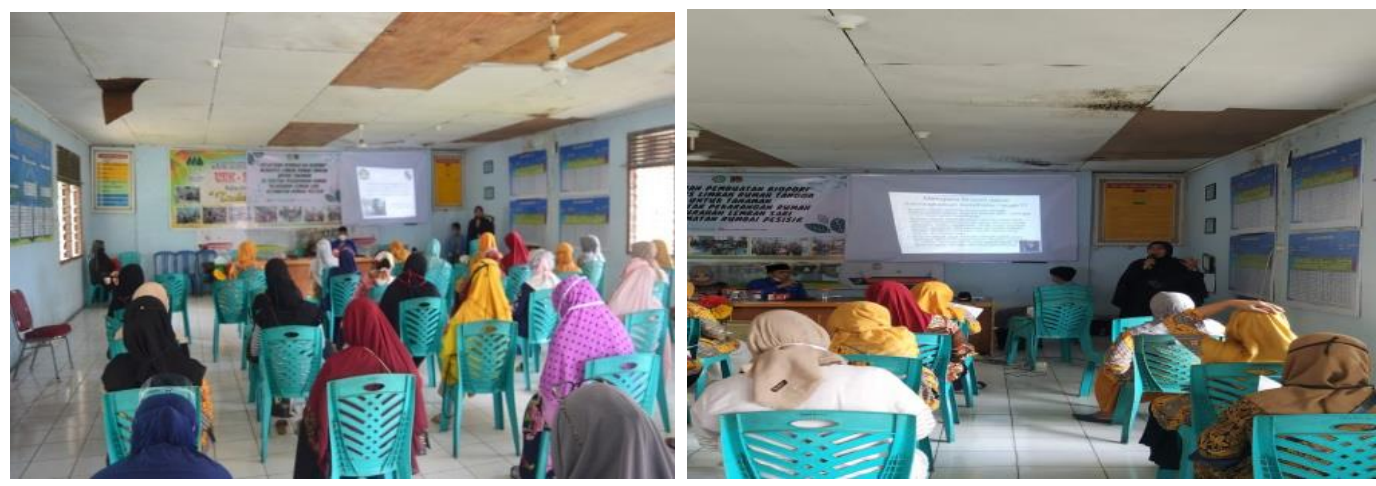

Gambar 4. Pemaparan materi biopori oleh ketua tim pengabdian

Setelah dilakukan pemaparan dan diskusi, dilanjutkan dengan peragaan pembuatan biopori dengan menggunakan botol plastik yang telah disediakan oleh tim pengabdian. Hal ini dilakukan agar proses pelubangan botol plastik tidak salah sehingga nantinya peranan biopori untuk kesuburan tanah maksimal. Proses peragaan pembuatan biopori dapat dilihat pada Gambar 5.

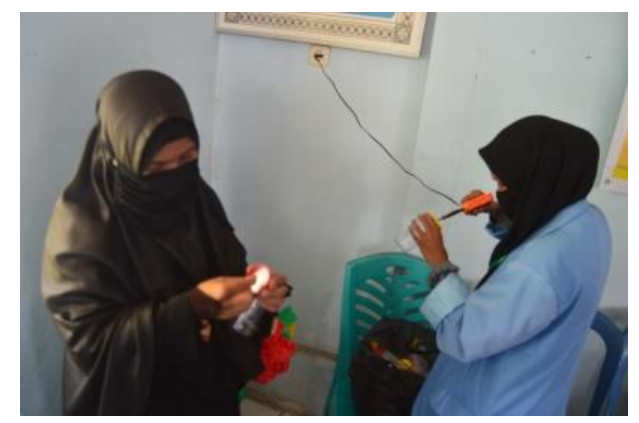

Gambar 5. Proses peragaan pelubangan botol untuk biopori

Setelah melakukan pemaparan, diskusi, dan peragaan, kegiatan dilanjutkan dengan pembagian bibit tanaman buah-buahaan oleh mahasiswa Kuliah Kerja Nyata kepada ibu-ibu PKK. Kegiatan ini dilakukan dalam rangka menambah koleksi tanaman buah-buahan yang dimiliki oleh ibu-ibu PKK. Bibit tanaman yang diberikan di antaranya yaitu tanaman sirsak, durian, dan manggis. Bibit ini merupakan bantuan dari Sekolah Kehutanan Kota Pekanbaru. Pemberian bantuan bibit kepada ibu PKK dapat dilihat pada Gambar 6. 

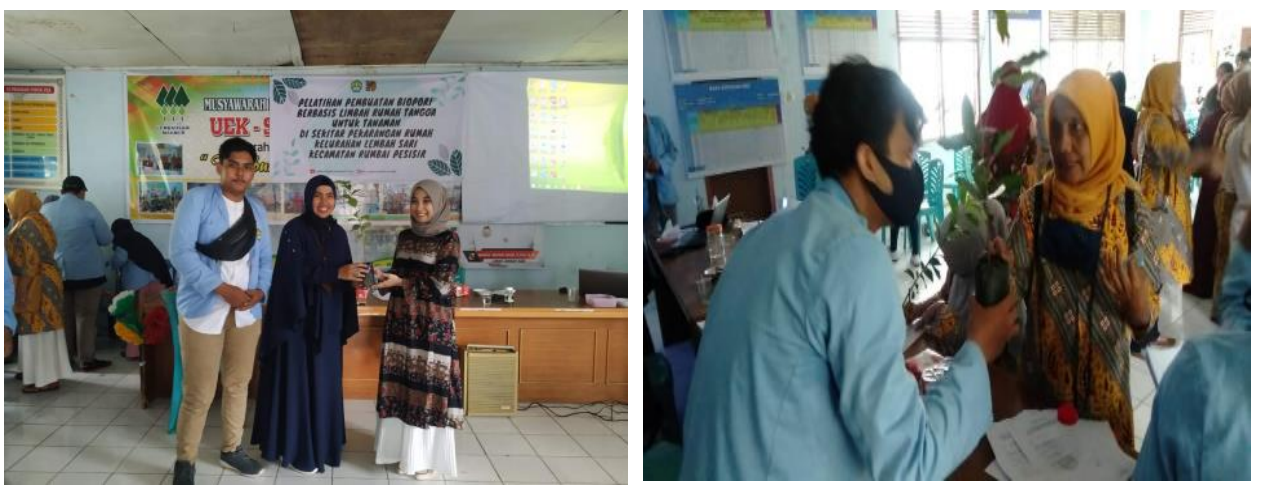

Gambar 6. Penyerahan bantuan bibit kepada kelompom ibu PKK Kelurahan Lembah Sari

Sebelum kegiatan pengabdian diakhiri, dilakukan pembagian kuisioner kembali (posttest) sebagai tolak ukur efektivitas kegiatan pengabdian yang dilakukan. Berdasarkan hasil posttest yang dilakukan, semua peserta kegiatan $(100 \%)$ telah memahami tentang manfaat biopori untuk kesuburan tanah mapun cara aplikasi biopori. Peserta juga tertarik untuk mempraktekkan langsung pembuatan biopori pada tanaman sekitar pekarangan rumahnya. Hal ini dapat dilihat pada Gambar 7.
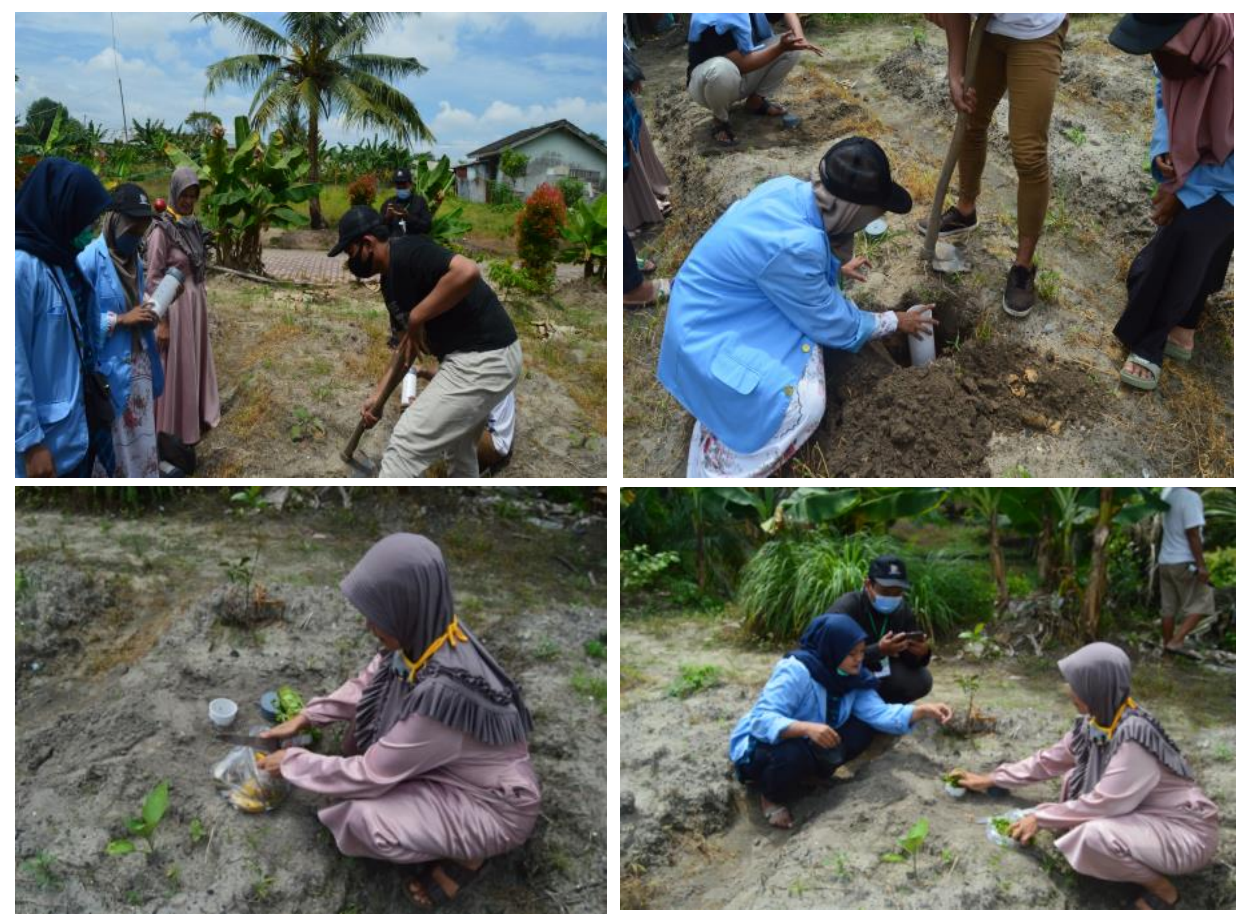

Gambar 7. Aplikasi biopori secara langsung pada lahan budidaya tanaman pada salah satu ibu-ibu PKK Lembah Sari

Pada Gambar 7 terlihat bahwa kegiatan biopori ini cukup efektif dalam meningkatkan minat ibu PKK untuk dapat mempraktekkan secara langsung biopori di sekitar tanaman yang dibudidayakan. Salah satu anggota PKK ini memiliki mata pencaharian sampingan sebagai petani sehingga dia sangat tertarik untuk dapat menerapkan biopori sebagai upaya penanggulangan limbah rumah tangga dan dapat mengurangi penggunaan pupuk anorganik yang pastinya mengeluarkan biaya. Dengan kata lain, selain dapat diterapkan pada skala ibu rumah tangga, program biopori ini juga dapat mengurangi pengeluaran petani dalam hal pemupukan sehingga nantinya dapat meningkatkan pendapatan petani di Kelurahan Lembah Sari Kecamatan Rumbai Pesisir Kota Pekanbaru. 


\section{KESIMPULAN}

Berdasarkan kegiatan pengabdian yang telah dilaksanakan dapat disimpulkan bahwa kegiatan pengabdian ini cukup efektif dalam meningkatkan pemahaman maupun minat ibu-ibu PKK terhadap pemanfaatan biopori berbasis limbah rumah tangga. Hal ini terbukti dari persentase peserta yang memahami tentang biopori sebanyak $100 \%$ dan adanya peserta pengabdian yang langsung mempraktekkan biopori pada tanaman yang dibudidayakan di sekitar pekarangan rumahnya. Semakin banyak ibu-ibu yang mengaplikasikan biopori maka menjadi salah satu upaya mengurangi limbah yang berasal dari sampah rumah tangga. Hambatan selama kegiatan pengabdian ini yaitu belum terlihat dampak pertumbuhan tanaman yang telah diaplikasikan biopori pada tanaman yang dibudidayakan ibu PKK Kelurahan Lembah Sari.

\section{DAFTAR PUSTAKA}

Abidin Z dan M. Rohman. 2020. Pemberdayaan kelompok tani dalam pembuatan pupuk organik berbahan baku limbah rumah tangga. Community Development Journal: Jurnal Pengabdian Masyarakat, 1(2), 89-94.

Permanasari, E, F. Handola, Sahid, R. Purisari, R. Safitri. 2018. Penyelamatan Air Tanah dan Penanggulangan Sampah Melalui Program Biopori dan Komposter di Pemukiman Kecil Kelurahan Ciputat dan Ciputat Timur. Jurnal Pengabdian kepada Masyarakat - Indonesian Journal of Community Engagement, 4(1), 51-64. http://doi.org/10.22146/jpkm.33412

Mansur, I dan R. P. Wijaya. 2019. Respon pertumbuhan jabon (Anthocephalus Cadamba (Roxb.) Miq.) terhadap lubang resapan biopori pada lahan bekas tambang. Jurnal Silvikultur Tropika, 10(03), 146-151.

Santoso S, E. Soekendarsi, M.S. Hassan, Fahruddin, M. Litaay, D. Priosambodo. 2018. Biopori dan Biogranul Kompos Sebagai Upaya Peningkatan Peduli Lingkungan di SMA N 4 Kabupaten Soppeng. Jurnal Abdimas Unmer Malang, 3. https://doi.org/10.26905/abdimas.v3i0.2668

Zulaiha, L, A. H. Siregar, A. Marasabessy. 2018. Pengelola Sampah Organik Berbasis Biopori di Kelurahan Bojong Kulur, Kecamatan Gunung Putri, Kabupaten Bogor. Prosiding seminar nasional dan pengabdian pada masyarakat. Pangkalpinang. ISBN: 978-602-61545-0-7. 